\title{
The association of ultrafiltration with the outcomes of cardiopulmonary bypass surgery in adults with cardiovascular disease: The result of a systematic review and meta-analysis
}

\author{
Mohammed Al-Sadawi ${ }^{1}$, Farzane Saeidifard ${ }^{2}$, Romy R Ortega ${ }^{1}$, Patricia Erwin ${ }^{3}$, Mohammad Abdallat ${ }^{4}$, Falah Abuhassan ${ }^{5}$ and Adam S \\ Budzikowski $^{6 *}$ \\ ${ }^{1}$ Department of Internal Medicine, SUNY Downstate Medical Center 450 Clarkson Ave, Brooklyn, NY, USA \\ ${ }^{2}$ Department of Internal Medicine, Lenox Hill Hospital, Northwell Health, Zucker School of Medicine 130 E 77th St, New York, NY, USA \\ ${ }^{3}$ Division of Preventive Cardiology, Department of Cardiovascular Medicine, Mayo Clinic1st St SW, Rochester, MN, USA \\ ${ }^{4}$ Department of Surgery, Brookdale University Hospital and Medical Center, USA \\ ${ }^{5}$ Department of General Surgery, Princess of Wales hospital, Bridgend, CF31 1RQ, UK \\ ${ }^{6}$ Division of Cardiovascular Medicine, Department of Medicine, SUNY Downstate Medical Center 450 Clarkson Ave, Brooklyn, NY, USA
}

\begin{abstract}
Introduction: Previous studies have shown that ultrafiltration (UF) is associated with improved minor and major outcomes of cardiopulmonary bypass (CPB) by improving tissue perfusion as well as lowering the patient's hematocrit and blood loss and finally reducing the mortality. This meta-analysis aimed to pool the data of the previous studies on the association between using UF in the perioperative period and clinical outcomes in adult patients undergoing CPB.
\end{abstract}

Methods: We searched Ovid MEDLINE, Ovid Embase Scopus, Web of Science, Google Scholar, and EBSCO CINAHL from inception up to June 29th, 2019. The studies that assessed the association of UF with the outcomes of CPB in adults were eligible for inclusion. We did not restrict the search to time or language. Two independent investigators screened the identified studies and extracted the data in duplicate. We analyzed sixteen different clinical outcomes. Heterogeneity was assessed using Cochrane collaboration tools.

Results: Primary search identified 1114 studies from which 22 studies with 8538 patients were found eligible for inclusion. Results showed a statistically significant reduction in perioperative bleeding $(-107.59$ (ml) CI [-179.01, -36.18]), red blood cell transfusion (-0.76 (unit/patient) CI [-1.02,-0.51]) and ICU length of stay $(-0.16$ (day) CI $[-0.31,-0.01])$ in the group with UF compared to the control group. Aortic cross-clamp time, CPB time, ventilation time, hospital length of stay, as well as number of myocardial infarctions, chest infection, perioperative arrhythmia, low cardiac output, stroke/TIA, acute renal failure, intra-aortic balloon pump, reoperation and mortality was not statistically different between the two groups $(\mathrm{p}=>0.05)$.

Conclusion: Using UF in adult patients undergoing CPB is associated with reduced perioperative bleeding, red blood cell transfusion, and ICU length of stay. However, the use of UF was not associated with the reduction of major cardiovascular outcomes.

\section{Introduction}

Cardiopulmonary bypass (CPB) contributes to hemodilution, coagulation abnormalities, activation of inflammatory mediators, and as a result end-organ dysfunction in cardiac surgery [1]. This hemodilution occurs due to the use of priming solution that fills the circuit before perfusion begins, it can be further exacerbated using cardioplegia solution. Once CPD is discontinues this hemodiluted blood remain in the extracorporeal circuit and is slowly transfused back to the patient during or after aortic decannulation.

This hemodilution after CBP can be reversed or reduced by Ultrafiltration (UF), in which cell-free fluid is removed from the circulation. Utilizing a semipermeable membrane that allow for the transfer of water, electrolytes, and small molecules (on average up to $20 \mathrm{kDa}$ ) which may reduce transfusion requirements, inflammatory mediators [2] and improve hypercoagulability, post bypass hemodynamics and end-organ perfusion [3,4]. Excess removal of circulating volume has been linked to induce renal dysfunction in UF [5]. The two main forms of UF are conventional UF (CUF) which is run during CBP and cannot run following its discontinuation. In contrast, modified UF (MUF) is performed after completion of CBP, utilizing the aortic cannula.

In the pediatric population UF has been established as standard of care after CBP given its pronounced benefits [6]. Several randomized

*Correspondence to: Adam S Budzikowski, Division of Cardiovascular Medicine, Department of Medicine, SUNY Downstate Medical Center 450 Clarkson Ave, Brooklyn, NY, United States, E-mail: abudzikowski@downstate.edu

Key words: hemofiltration, ultrafiltration, cardiopulmonary bypass surgery, $C A B G$, cardiac surgery, systematic review, meta-analysis

Received: July 02, 2020; Accepted: July 13, 2020; Published: July 23, 2020 
Al-Sadawi M (2020) The association of ultrafiltration with the outcomes of cardiopulmonary bypass surgery in adults with cardiovascular disease: The result of a systematic review and meta-analysis

trials have tried to establish the effect of UF in adult undergoing cardiac surgery. All these studies had an intervention and control group, mortality, and other surrogate endpoints like ICU length of stay, cardiovascular events, acute kidney injury, and transfusion requirements were studied. The aim of this study is to evaluate the existing evidence on the use of UF, (whether CUF or MUF) in adults that undergoing $\mathrm{CBP}$ and its possible benefits.

\section{Methods}

\section{Data source and study selection}

This meta-analysis was conducted using a preplanned protocol. All results were reported according to the Preferred Reporting Items for Systematic Reviews and Meta-Analyses (PRISMA) guidelines. With the assistance of an expert librarian, Ovid MEDLINE, Ovid, Embase, Scopus, Web of Science, Google Scholar, and EBSCO CINAHL were searched from their inception up to June 29th, 2019. The search was not restricted to time, publication status or language. All relevant references and Authors' (of the included studies) related publication hand-searched for relevant studies. Medical Subject Headings (MeSH) terms were used with keywords for UF, cardiac surgery, and adult. We included randomized and quasi-randomized designs, pre-post trials, cross-sectional studies, and observational studies. Only studies on using UF in adult patients undergoing CBP and have a control group were included in the meta-analysis without restriction to the type of cardiac surgery.

Studies search and selection is illustrated in (Figure 1). Our primary search identified 1559 potentially eligible studies. Duplicates were excluded and 1114 studies were included for screening, each title and abstract were evaluated by two reviewers independently using a systematic review software (Covidence, London, UK), 45 publications were retrieved, and their manuscripts were evaluated for possible inclusion. A total of 22 studies met all eligibility criteria and were included in our meta-analysis after the agreement of the two reviewers.

\section{Data extraction and analysis}

Data extraction was done by two independent reviewers with discrepancies resolved by consensus. Data included: first author, date of

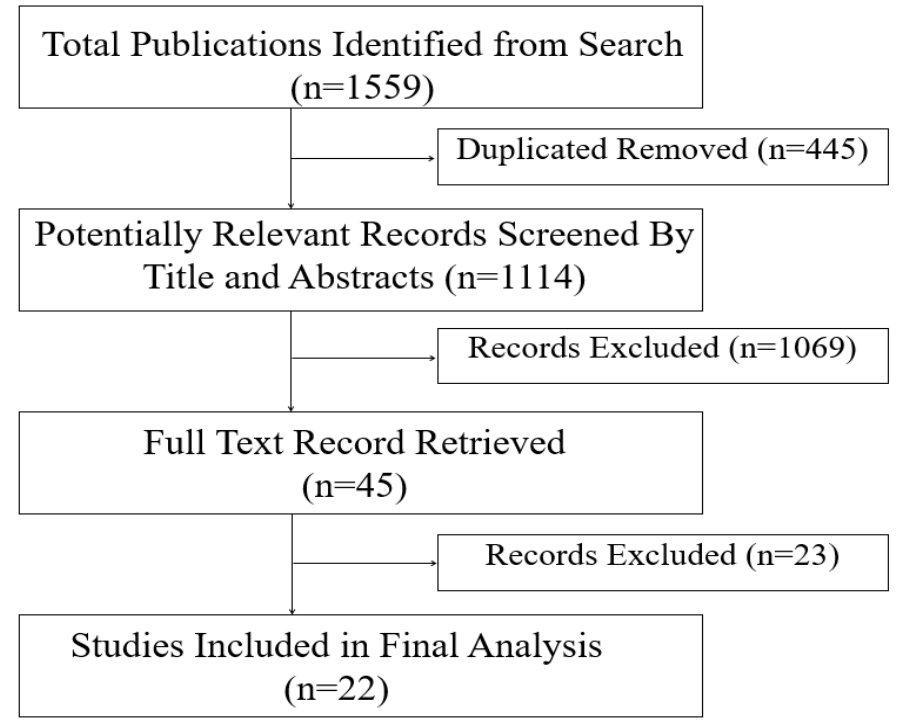

Figure 1. PRISMA flowchart describing the study's systematic literature search and study selection publishing, methods, risk of bias assessment, participants, intervention and control groups, and results (dichotomous or continuous outcomes).

In addition to the primary end point of perioperative bleed, PRBC transfusion, ICU length of stay, the following clinical parameters were collected: average aorta cross-clamp (ACC) time, average CPB time, ventilation time, hospital length of stay, myocardial infarction, Pulmonary complications, perioperative arrhythmia, low cardiac output, stroke/TIA, acute renal failure, the use of intra-aortic balloon pump, reoperation and mortality.

The meta-analysis was performed using Review Manager, version 5 (Cochrane Collaboration). Mean differences were evaluated along with 95\% confidence intervals (95\% CIs). All parameters were summarized using the random-effects model. Heterogeneity was tested using I2 index for each outcome. Risk of bias was assessed using Cochrane collaboration tools.

\section{Results}

We included 22 observational studies in our analysis, baseline characters are presented in (Table 1) [1,5,7-26]. In the intervention group there was a statistically significant reduction in in postoperative bleeding (ml) (-107.59 CI [-179.01, -36.18]), postoperative blood transfusion (unit/pt) $(-0.76 \mathrm{CI}[-1.02,0.51])$ and ICU length of stay $(-0.16 \mathrm{CI}[-0.31,0.01])$. There were no statistically significant differences between both groups in average ACC time is $(-0.69$ CI $[-0.2,0.62])$, average CPB time $(-0.85$ CI $[-1087,0.16])$, ventilation time $(-0.86 \mathrm{CI}$ $[-3.08,1.37])$, hospital length of stay $(-0.41$ CI $[-1.0,0.18])$, mortality (0.94 CI $[0.65,1.37])$, myocardial infarction $(0.62 \mathrm{CI}[0.33,1.16])$, chest infection (-0.69 CI $[0.25,1.15])$, perioperative arrhythmia $(1.23 \mathrm{CI}$ $[0.81,1.85])$, low cardiac output $(0.92 \mathrm{CI}[0.43,1.95])$, stroke/ Transient Ischemic Attack (TIA) (0.85 CI [0.56,1.29]), acute renal failure (1.1 CI $[0.81,1.49])$, intra-aortic balloon pump (0.75 CI [0.24,2.36]), and reoperation $(0.99 \mathrm{CI}[0.65,1.5])$.

\section{Discussion}

This was the first systematic review and meta-analysis about this subject. We included 22 studies evaluating the utility of UF in adult undergoing cardiac surgery. Among the studies included, sixteen different outcomes were analyzed including mortality. In this systematic analysis the only endpoints that demonstrated a statistically significant difference were post-operative bleeding, transfusion of RBCs and length of stay in the ICU. There was no evidence of mortality benefit which corroborates every single study included in this analysis.

The results of the present study showed that UF is associated with decrease in post-operative bleeding, transfusion of RBCs and length of stay in the ICU but not with major cardiovascular outcomes.

Ultrafiltration have shown to improve postoperative hemodynamics and myocardial recovery as well as cerebral and hemostatic function in pediatric cardiac surgery [27], with these benefits UF has been adapted as the standard of care in this population. The value of UF in adult cardiac surgery has not been thoroughly explored. We conducted this meta-analysis to better evaluate the utility of UF, Both MUF and CUF in adult (Figure 2-17).

The main benefit that has been consistent with the use of UF is a decrease in transfusion requirements. Multiple studies have demonstrated that these appears to be driven by correcting hemodilution and less post-operative bleeding. Our study found a statistically significant decrease in post-operative bleeding. This was 
Al-Sadawi M (2020) The association of ultrafiltration with the outcomes of cardiopulmonary bypass surgery in adults with cardiovascular disease: The result of a systematic review and meta-analysis

Table 1. Demographic data of the studies \pm

\begin{tabular}{|c|c|c|c|c|c|c|}
\hline Study & \multicolumn{2}{|c|}{ Number of participants } & \multirow{2}{*}{$\begin{array}{c}\text { Number of participants } \\
30\end{array}$} & \multirow{2}{*}{$\begin{array}{c}\text { Male (\%) } \\
70\end{array}$} & \multirow{2}{*}{$\begin{array}{c}\text { CABG (\%) } \\
100\end{array}$} & \multirow{2}{*}{$\begin{array}{c}\text { Age }( \pm \text { SD) } \\
63( \pm 9)\end{array}$} \\
\hline \multirow{2}{*}{ Babka 1997} & 60 & Intervention & & & & \\
\hline & & Control & 30 & 87 & 100 & $59( \pm 11)$ \\
\hline \multirow{2}{*}{ Blanchard 2000} & 26 & Intervention & 13 & 69 & 100 & 66 \\
\hline & & Control & 13 & 69 & 100 & 66 \\
\hline \multirow{2}{*}{ Boga 2000} & 40 & Intervention & 20 & 80 & 100 & $58( \pm 11)$ \\
\hline & & Control & 20 & 70 & 100 & $61( \pm 8)$ \\
\hline \multirow{2}{*}{ Boodhwani 2009} & 65 & Intervention & 29 & 66 & & $66( \pm 13)$ \\
\hline & & Control & 36 & 78 & & $71( \pm 10)$ \\
\hline \multirow{2}{*}{ Coskun 2013} & 46 & Intervention & 26 & 89 & 89 & $58( \pm 7)$ \\
\hline & & Control & 20 & 70 & 80 & $58( \pm 11)$ \\
\hline \multirow{2}{*}{ De Baar 2003} & 60 & Intervention & 29 & 79 & 100 & $66( \pm 9)$ \\
\hline & & Control & 31 & 74 & 100 & $67( \pm 8)$ \\
\hline \multirow{2}{*}{ El-Tahan 2010} & 60 & Intervention & 30 & 60 & & 28 \\
\hline & & Control & 30 & 70 & & 27 \\
\hline \multirow{2}{*}{ Kiziltepe 2001} & 40 & Intervention & 20 & 65 & 75 & $60( \pm 14)$ \\
\hline & & Control & 20 & 70 & 75 & $60( \pm 8)$ \\
\hline \multirow{2}{*}{ Luciani 2001} & 573 & Intervention & 284 & 66 & 57 & $64( \pm 11)$ \\
\hline & & Control & 289 & 74 & 60 & $63( \pm 14)$ \\
\hline \multirow{2}{*}{ Matata 2015} & 199 & Intervention & 97 & 59 & 31 & 76 \\
\hline & & Control & 102 & 60 & 30 & 73 \\
\hline \multirow{2}{*}{ Oliver 2004} & 127 & Intervention & 64 & 84 & 44 & $62( \pm 1)$ \\
\hline & & Control & 63 & 83 & 57 & $62( \pm 12)$ \\
\hline \multirow{2}{*}{ Papadopolous 2013} & 50 & Intervention & 25 & 52 & & $74( \pm 6)$ \\
\hline & & Control & 25 & 64 & & $75( \pm 5)$ \\
\hline \multirow{2}{*}{ Paugh 2015} & 6407 & Intervention & 1362 & 75 & & \\
\hline & & Control & 5045 & 75 & & \\
\hline \multirow{2}{*}{ Soliman 2016} & 283 & Intervention & 138 & 50 & 53 & $60( \pm 12)$ \\
\hline & & Control & 145 & 42 & 47 & $60( \pm 12)$ \\
\hline \multirow{2}{*}{ Zhang 2009} & 94 & Intervention & 47 & & & \\
\hline & & Control & 47 & & & \\
\hline \multirow{2}{*}{ Naveed 2015} & 80 & Intervention & 40 & 72 & 16 & $47( \pm 13)$ \\
\hline & & Control & 40 & 82 & 24 & $51( \pm 9)$ \\
\hline \multirow{2}{*}{ Torina 2012} & 60 & Intervention & 30 & 80 & 100 & $55( \pm 7)$ \\
\hline & & Control & 30 & 93 & 100 & $56( \pm 9)$ \\
\hline \multirow{2}{*}{ Grunenfelder 2000} & 50 & Intervention & 30 & & 100 & \\
\hline & & Control & 20 & & 100 & \\
\hline Tollman 2002 & 30 & Intervention & 15 & 66 & & $63( \pm 9)$ \\
\hline $1011 m a n 2002$ & & Control & 15 & 80 & & $63( \pm 7)$ \\
\hline Raman 2003 & 118 & Intervention & 61 & 66 & 39 & $68( \pm 12)$ \\
\hline Kaman 2003 & & Control & 57 & 77 & 35 & $65( \pm 13)$ \\
\hline Steffens 2008 & 30 & Intervention & 15 & 90 & & $58( \pm 11)$ \\
\hline Stentens 2000 & & Control & 15 & 66 & & $58( \pm 16)$ \\
\hline Kosour 2016 & 40 & Intervention & 20 & 64 & 100 & $59( \pm 10)$ \\
\hline Kosour 2010 & & Control & 20 & 75 & 100 & $60( \pm 10)$ \\
\hline
\end{tabular}

driven by two of the studies $[11,13]$ that reported a decrease in mean post-operative bleeding of 200 to $250 \mathrm{~mL}$. Three other studies have demonstrated a trend towards less post-operative bleeding without reaching statistical significance $[14,22,23]$. This decrease in bleeding was likely one of the main contributors to the reduction on transfusion requirements of 0.76 units/patient ( $95 \% \mathrm{CI}:-1.02,-0.51$ ), which is also explained by the reduction in hemodilution after CBP, at least 6 of the studies included demonstrated a significant decrease in units transfused or at least a trend towards significance.

Nine Studies which reported mortality as an endpoint were included. In a multicenter, observational cohort study which assessed the effect of UF (CUF) versus control group [5], there was no significant difference in mortality rate between patients who have received CUF and those who have not. A result which has been consistent among all the manuscripts included. On the other hand, Paugh et al. [5] did found differences in morbidity, mainly rates of acute kidney injury which were greater in the CUF group (adjusted OR 1.36; 95\% confidence interval, 1.12 to $1.65 ; \mathrm{p}=0.002$ ).

The risk of acute kidney injury (AKI) is of great interest when studying UF. Several mechanisms can contribute to AKI; both fluid overload as a result of CBP as well as excessive fluid removal during UF can potentially impact renal function. Our results demonstrate no significant impact of UF on renal function. All 6 studies which investigated AKI after filtration did not demonstrate a clear benefit or harm of using UF. Paugh et al. [5] demonstrated an increased risk of developing AKI after CPB and UF which appeared to be mainly related to increasing volume of UF in patients with baseline chronic kidney injury. This might be explained by the excessive risk of developing AKI 
Al-Sadawi M (2020) The association of ultrafiltration with the outcomes of cardiopulmonary bypass surgery in adults with cardiovascular disease: The result of a systematic review and meta-analysis

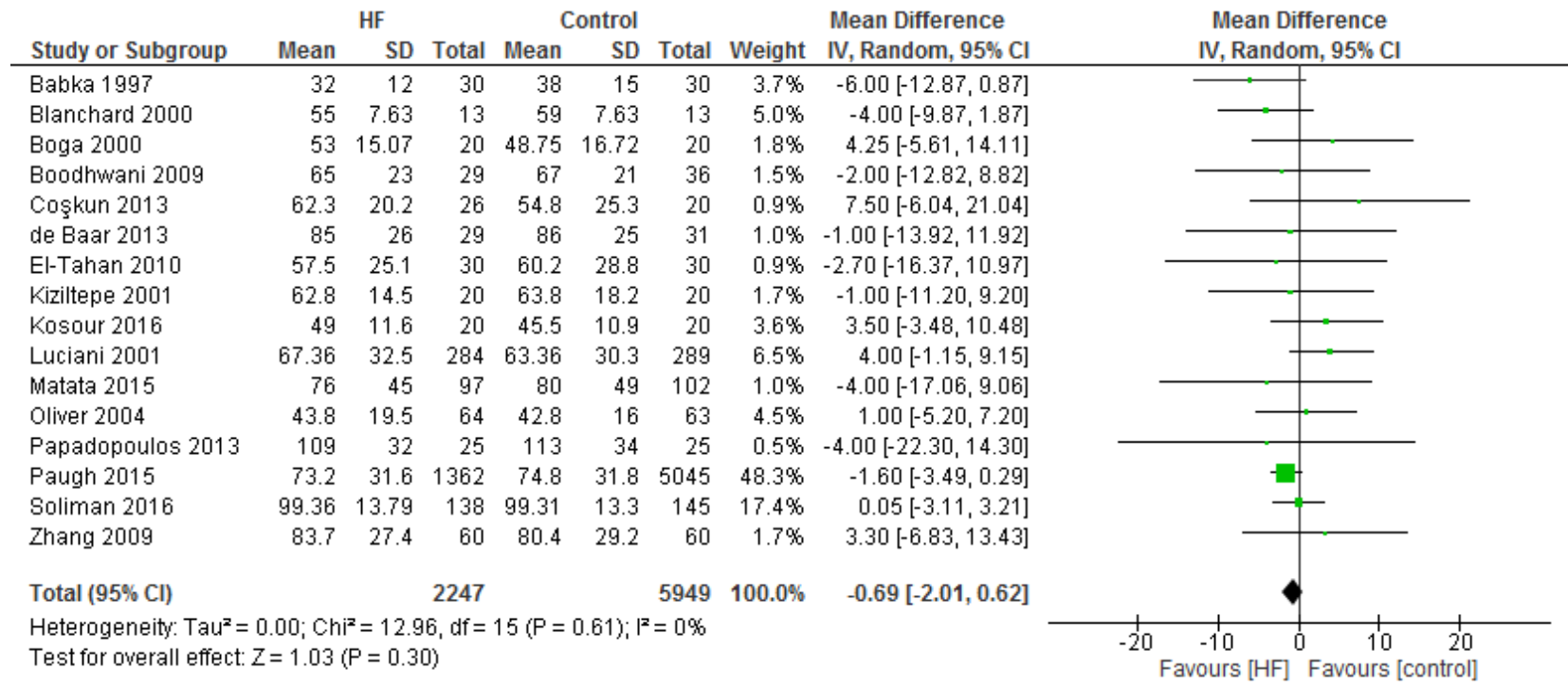

Figure 2. The results of meta-analysis on the association of Ultrafiltration and the average aorta cross-clamp (ACC) time in minutes

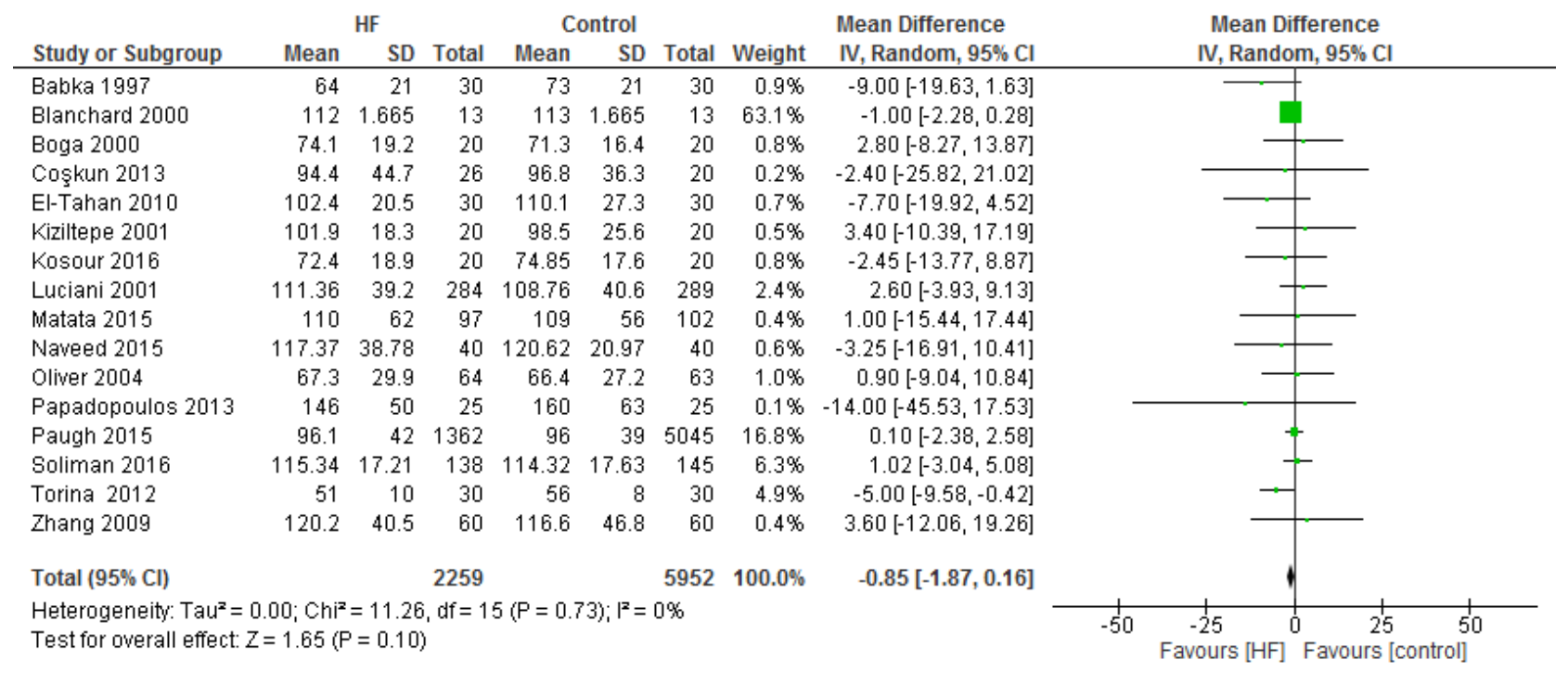

Figure 3. The results of meta-analysis on the association of Ultrafiltration and the average cardiopulmonary bypass (CPB) time in minutes

\begin{tabular}{|c|c|c|c|c|c|c|c|c|c|}
\hline \multirow[b]{2}{*}{ Study or Subgroup } & \multicolumn{3}{|c|}{ HF } & \multicolumn{3}{|c|}{ Control } & \multicolumn{2}{|r|}{ Mean Difference } & \multirow{2}{*}{$\begin{array}{c}\text { Mean Difference } \\
\text { IV, Random, } 95 \% \mathrm{Cl}[\mathrm{hr}]\end{array}$} \\
\hline & Mean [hr] & $\mathrm{SD}[\mathrm{hr}]$ & Total & Mean [hr] & SD [hr] & Total & Weight & IV, Random, $95 \% \mathrm{Cl}[\mathrm{hr}]$ & \\
\hline Coşkun 2013 & 14 & 5 & 26 & 12.7 & 7 & 20 & $9.1 \%$ & $1.30[-2.32,4.92]$ & \\
\hline de Baar 2013 & 17 & 3.6 & 29 & 23.3 & 21 & 31 & $5.1 \%$ & $-6.30[-13.81,1.21]$ & \\
\hline El-Tahan 2010 & 5.5 & 2.41 & 30 & 8.6 & 6.21 & 30 & $10.5 \%$ & $-3.10[-5.48,-0.72]$ & \\
\hline GruÈnenfelder 1999 & 15.4 & 9.2749 & 60 & 14.873 & 4.6876 & 37 & $10.1 \%$ & $0.53[-2.26,3.32]$ & \\
\hline Kiziltepe 2001 & 11.9 & 4.1 & 20 & 14.1 & 12.9 & 20 & $6.5 \%$ & $-2.20[-8.13,3.73]$ & \\
\hline Kosour 2016 & 6 & 3.52 & 20 & 4 & 1.76 & 20 & $11.2 \%$ & $2.00[0.28,3.72]$ & - \\
\hline Luciani 2001 & 22.56 & 41.3 & 284 & 27.66 & 64 & 289 & $4.2 \%$ & $-5.10[-13.90,3.70]$ & \\
\hline Matata 2015 & 12 & 11 & 97 & 9 & 8 & 102 & $10.2 \%$ & $3.00[0.32,5.68]$ & - \\
\hline Oliver 2004 & 8.016 & 5.14 & 64 & 10.3 & 6.75 & 63 & $10.8 \%$ & $-2.28[-4.37,-0.19]$ & \\
\hline Tallman 2002 & 10.23 & 3.94 & 15 & 8.34 & 2.29 & 15 & $10.6 \%$ & $1.89[-0.42,4.20]$ & - \\
\hline Zhang 2009 & 14.35 & 1.66 & 60 & 18.64 & 1.57 & 60 & $11.9 \%$ & $-4.29[-4.87,-3.71]$ & - \\
\hline Total $(95 \% \mathrm{Cl})$ & & & 705 & & & 687 & $100.0 \%$ & $-0.86[-3.08,1.37]$ & \\
\hline \multicolumn{9}{|c|}{$\begin{array}{l}\text { Heterogeneity: } \operatorname{Tau}^{2}=10.79 ; \mathrm{Chi}^{2}=100.75, \mathrm{df}=10(\mathrm{P}<0.00001) ; \mathrm{I}^{2}=90 \% \\
\text { Test for overall effect: } Z=0.75(P=0.45)\end{array}$} & $\begin{array}{ccccc}-20 & -10 & 0 & 10 & 20 \\
\text { Favours }[\mathrm{HF}] & \text { Favours }[\mathrm{c}\end{array}$ \\
\hline
\end{tabular}

Figure 4. The results of meta-analysis on the association of Ultrafiltration and the ventilation time in hours 
Al-Sadawi M (2020) The association of ultrafiltration with the outcomes of cardiopulmonary bypass surgery in adults with cardiovascular disease: The result of a systematic review and meta-analysis

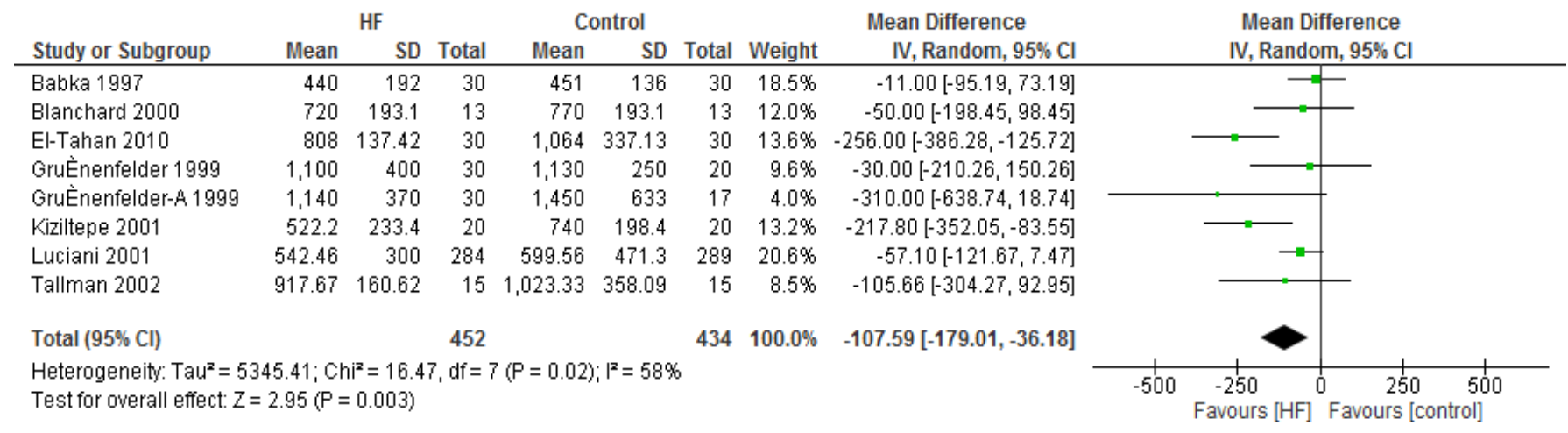

Figure 5. The results of meta-analysis on the association of Ultrafiltration and the perioperative bleed (ml)

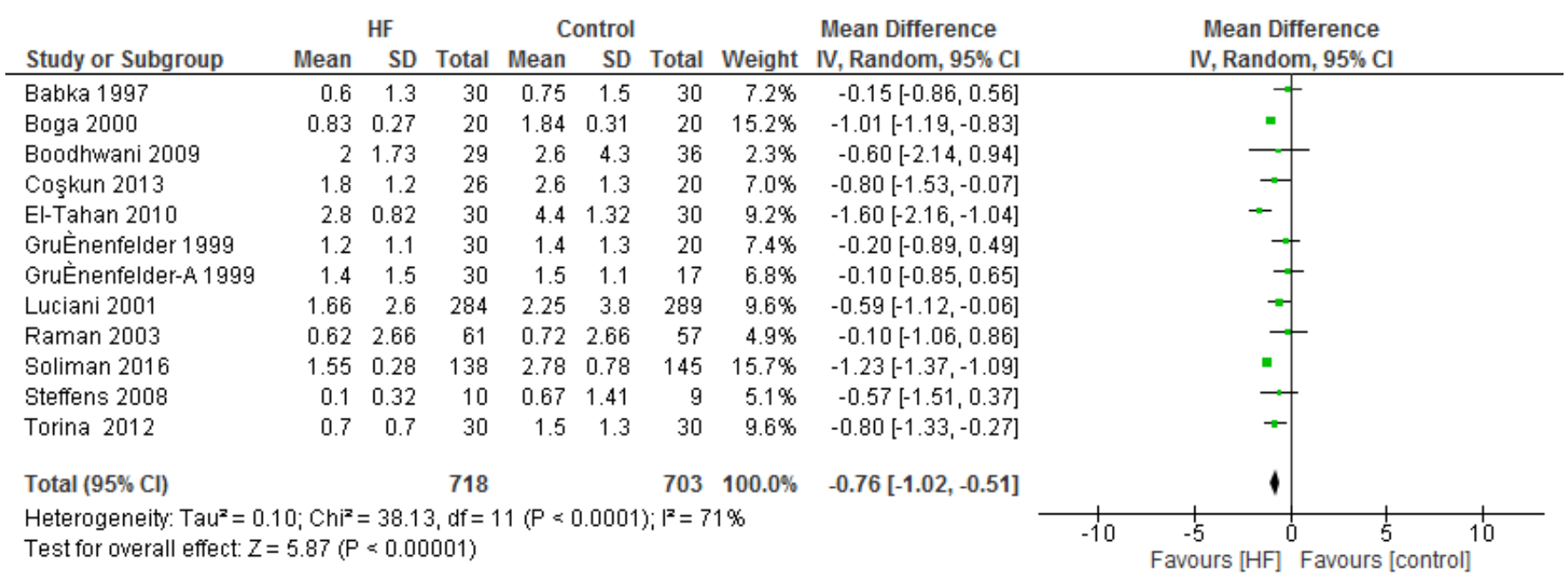

Figure 6. The results of meta-analysis on the association of Ultrafiltration and the red blood cells transfusion (unit/patient)

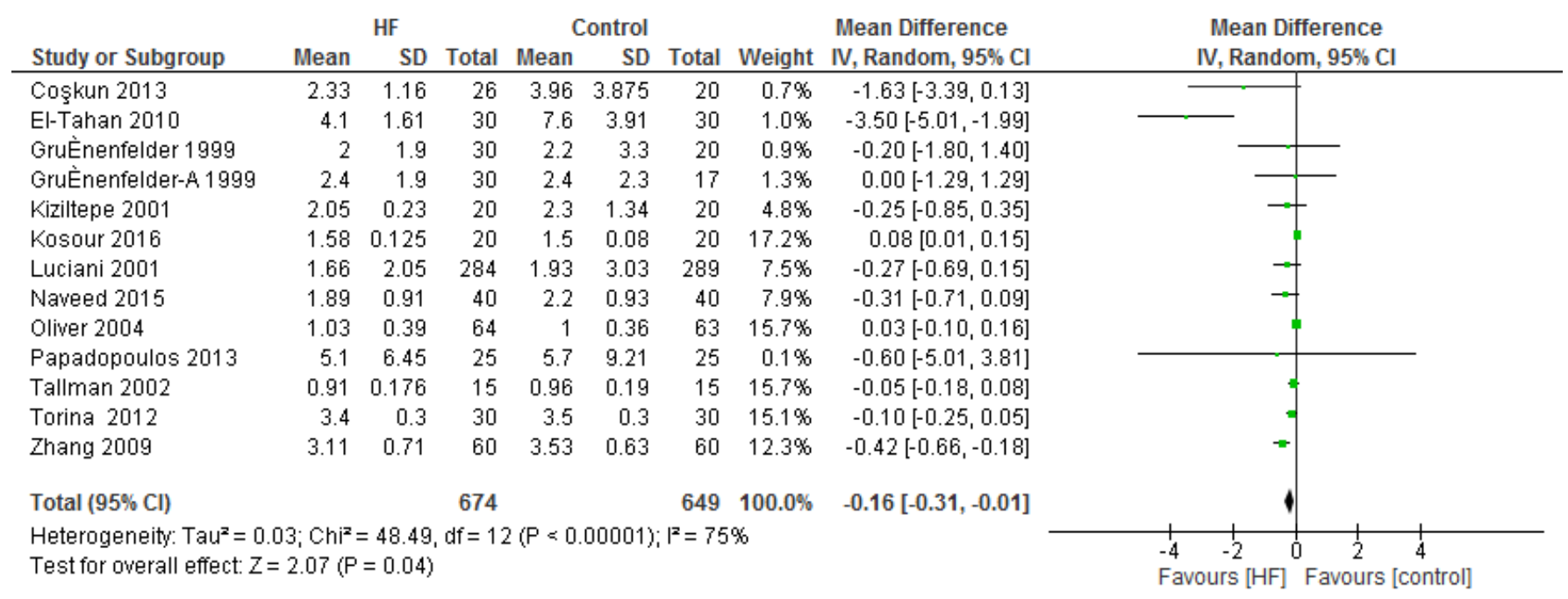

Figure 7. The results of meta-analysis on the association of Ultrafiltration and the ICU length of stay (days) 
Al-Sadawi M (2020) The association of ultrafiltration with the outcomes of cardiopulmonary bypass surgery in adults with cardiovascular disease: The result of a systematic review and meta-analysis

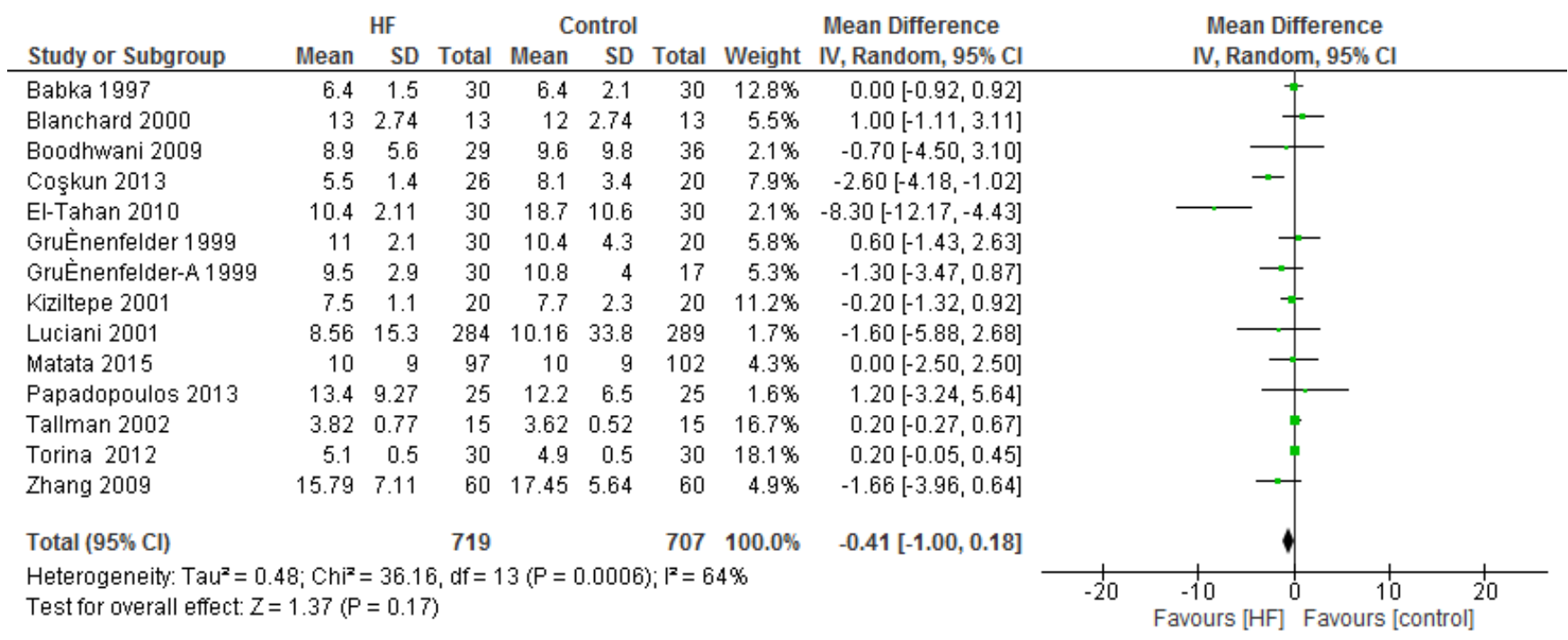

Figure 8. The results of meta-analysis on the association of Ultrafiltration and the hospital length of stay (days)

\begin{tabular}{|c|c|c|c|c|c|c|c|c|c|c|}
\hline Study or Subgroup & \multicolumn{2}{|c|}{ HF } & \multicolumn{2}{|c|}{ Control } & Weight & \multicolumn{2}{|l|}{ Odds Ratio } & \multicolumn{2}{|c|}{$\begin{array}{c}\text { Odds Ratio } \\
\text { M-H, Random, } 95 \% \mathrm{Cl}\end{array}$} & \\
\hline Coşkun 2013 & 1 & 26 & 1 & 20 & $1.7 \%$ & $0.76[0.04,12.95]$ & & & & \\
\hline El-Tahan 2010 & 1 & 30 & 2 & 30 & $2.3 \%$ & $0.48[0.04,5.63]$ & & & & \\
\hline Luciani 2001 & 7 & 284 & 11 & 289 & $14.9 \%$ & $0.64[0.24,1.67]$ & & $\longrightarrow$ & - & \\
\hline Matata 2015 & 3 & 97 & 10 & 102 & $7.9 \%$ & $0.29[0.08,1.10]$ & & & & \\
\hline Naveed 2015 & 1 & 40 & 3 & 40 & $2.6 \%$ & $0.32[0.03,3.18]$ & & & & \\
\hline Papadopoulos 2013 & 1 & 25 & 2 & 25 & $2.3 \%$ & $0.48[0.04,5.65]$ & & & & \\
\hline Paugh 2015 & 22 & 1362 & 60 & 5045 & $56.8 \%$ & $1.36[0.83,2.23]$ & & & 5 & \\
\hline Raman 2003 & 7 & 61 & 6 & 57 & $10.3 \%$ & $1.10[0.35,3.50]$ & & & & \\
\hline Zhang 2009 & 0 & 60 & 1 & 60 & $1.3 \%$ & $0.33[0.01,8.21]$ & & & & \\
\hline Total $(95 \% \mathrm{Cl})$ & & 1985 & & 5668 & $100.0 \%$ & $0.94[0.65,1.37]$ & & & & \\
\hline Total events & 43 & & 96 & & & & & & & \\
\hline $\begin{array}{l}\text { Heterogeneity: } \mathrm{Tau}^{2}= \\
\text { Test for overall effect: }\end{array}$ & $\begin{array}{l}.00 ; \mathrm{Chi}^{2} \\
=0.31(\mathrm{P}\end{array}$ & $\begin{array}{l}=7.79 \\
=0.75\end{array}$ & df $=8(F$ & $=0.45$ & $; 1^{2}=0 \%$ & & 0.001 & $\begin{array}{c}0.1 \\
\text { Favours [HF] }\end{array}$ & $\begin{array}{c}10 \\
\text { Favours }[\mathrm{c}\end{array}$ & 1000 \\
\hline
\end{tabular}

Figure 9. The results of meta-analysis on the association of Ultrafiltration and mortality

\begin{tabular}{|c|c|c|c|c|c|c|c|c|c|c|}
\hline Study or Subaroup & $\begin{array}{r}\text { HF } \\
\text { Events }\end{array}$ & Total & $\begin{array}{l}\text { Contr } \\
\text { Events }\end{array}$ & $\begin{array}{l}\text { ol } \\
\text { Total }\end{array}$ & Weight & $\begin{array}{c}\text { Odds Ratio } \\
\text { M-H. Random. } 95 \% \mathrm{Cl}\end{array}$ & & $\begin{array}{r}\text { Odds } \\
\text { M-H, Rand }\end{array}$ & $\begin{array}{l}\text { s Ratio } \\
\text { dom. } 95 \% \mathrm{Cl}\end{array}$ & \\
\hline Kiziltepe 2001 & 0 & 20 & 2 & 20 & $4.1 \%$ & $0.18[0.01,4.01]$ & & & 9 & \\
\hline Luciani 2001 & 15 & 284 & 21 & 289 & $84.5 \%$ & $0.71[0.36,1.41]$ & & & & \\
\hline Matata 2015 & 1 & 97 & 3 & 102 & $7.6 \%$ & $0.34[0.04,3.36]$ & & & & \\
\hline Zhang 2009 & 0 & 60 & 1 & 60 & $3.8 \%$ & $0.33[0.01,8.21]$ & & & & \\
\hline Total $(95 \% \mathrm{Cl})$ & & 461 & & 471 & $100.0 \%$ & $0.62[0.33,1.16]$ & & & & \\
\hline Total events & 16 & & 27 & & & & & & & \\
\hline \multicolumn{7}{|c|}{$\begin{array}{l}\text { Heterogeneity: } \mathrm{Tau}^{2}=0.00 ; \mathrm{Chi}^{2}=1.18, \mathrm{df}=3(\mathrm{P}=0.76) ; \mathrm{I}^{2}=0 \% \\
\text { Test for overall effect: } Z=1.50(\mathrm{P}=0.13)\end{array}$} & 0.005 & $\begin{array}{c}1 \\
0.1 \\
\text { Favours [HF] }\end{array}$ & $\begin{array}{cc}1 & 10 \\
\text { Favours [control] }\end{array}$ & 200 \\
\hline
\end{tabular}

Figure 10. The results of meta-analysis on the association of Ultrafiltration and the incidence of myocardial infarction 
Al-Sadawi M (2020) The association of ultrafiltration with the outcomes of cardiopulmonary bypass surgery in adults with cardiovascular disease: The result of a systematic review and meta-analysis

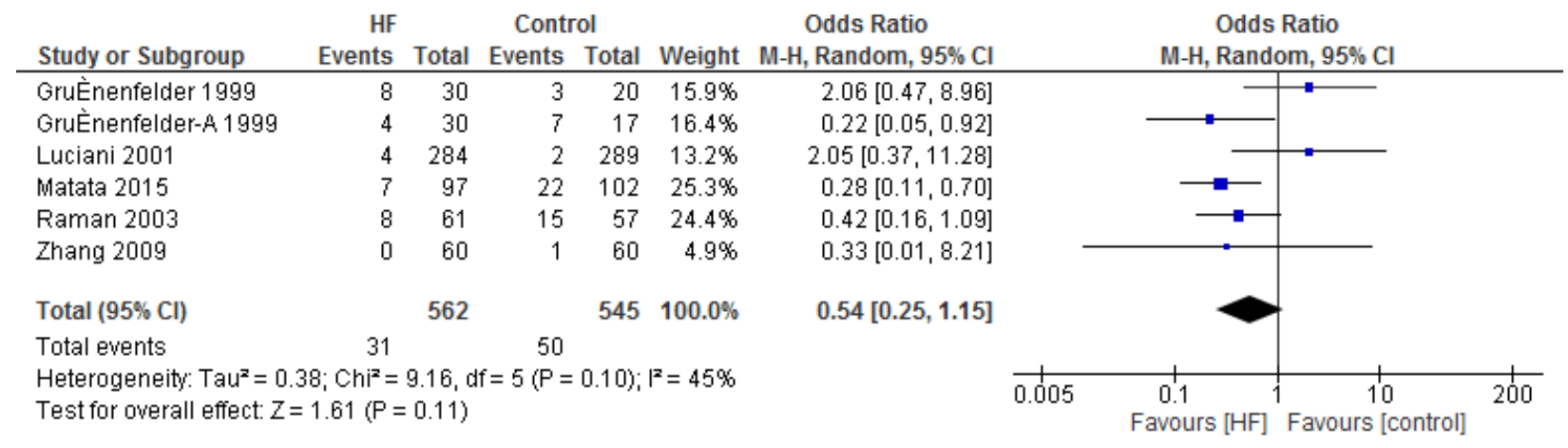

Figure 11. The results of meta-analysis on the association of Ultrafiltration and the chest infection incidence

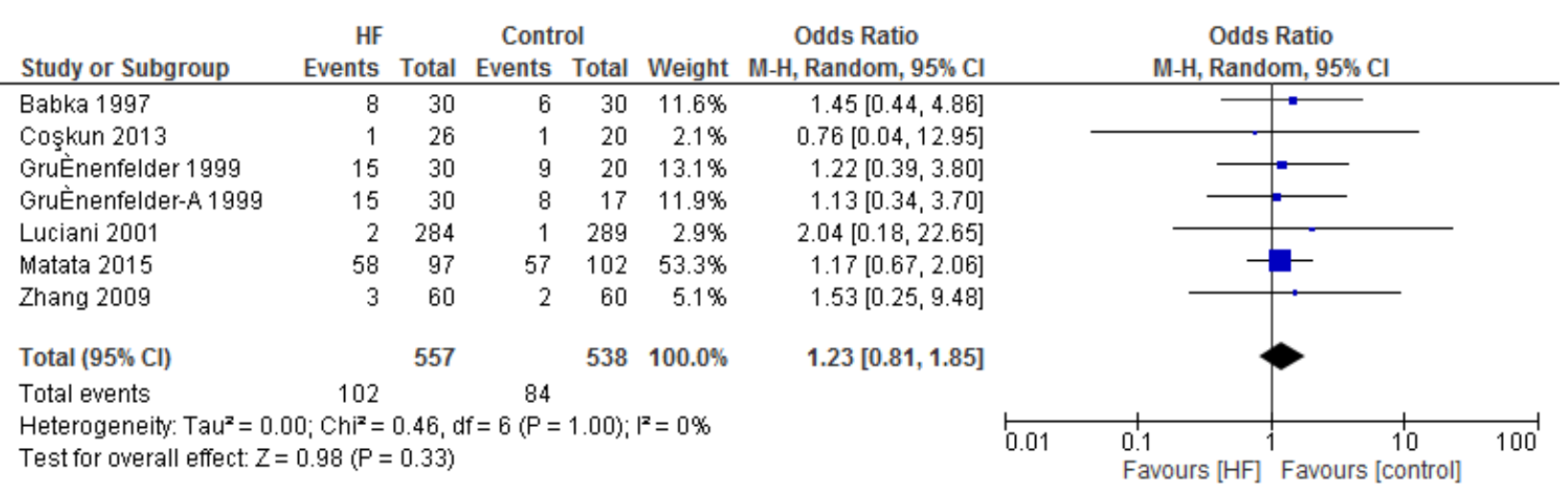

Figure 12. The results of meta-analysis on the association of Ultrafiltration and the perioperative arrhythmia

\begin{tabular}{|c|c|c|c|c|c|c|c|c|c|c|}
\hline Study or Subgroup & \multicolumn{2}{|l|}{ HF } & \multicolumn{2}{|c|}{ Control } & Weight & \multicolumn{2}{|l|}{ Odds Ratio } & \multicolumn{2}{|c|}{$\begin{array}{c}\text { Odds Ratio } \\
\text { M-H, Random, } 95 \% \mathrm{Cl}\end{array}$} & \\
\hline Kiziltepe 2001 & 4 & 20 & 4 & 20 & $13.9 \%$ & $1.00[0.21,4.71]$ & & & & \\
\hline Luciani 2001 & 9 & 284 & 13 & 289 & $23.5 \%$ & $0.69[0.29,1.65]$ & & & & \\
\hline Matata 2015 & 6 & 97 & 11 & 102 & $20.7 \%$ & $0.55[0.19,1.54]$ & & & & \\
\hline Paugh 2015 & 261 & 1362 & 555 & 5045 & $33.6 \%$ & $1.92[1.63,2.25]$ & & & $=$ & \\
\hline Zhang 2009 & 1 & 60 & 3 & 60 & $8.2 \%$ & $0.32[0.03,3.19]$ & & & & \\
\hline Total $(95 \% \mathrm{Cl})$ & & 1823 & & 5516 & $100.0 \%$ & $0.92[0.43,1.95]$ & & & & \\
\hline Total events & 281 & & 586 & & & & & & & \\
\hline $\begin{array}{l}\text { Heterogeneity: Tau }{ }^{2} \\
\text { Test for overall effec }\end{array}$ & $\begin{array}{l}0.43 ; \mathrm{Ch} \\
Z=0.22\end{array}$ & $\begin{array}{l}i^{2}=13 \\
(P=0.8\end{array}$ & $\begin{array}{l}06, d f=4 \\
2)\end{array}$ & $(P=0$. & $01) ;\left.\right|^{2}=6$ & $9 \%$ & 0.01 & $\begin{array}{l}0.1 \\
\text { Favours [HF] }\end{array}$ & $\begin{array}{c}10 \\
\text { Favours [control] }\end{array}$ & 100 \\
\hline
\end{tabular}

Figure 13. The results of meta-analysis on the association of Ultrafiltration and the low cardiac output

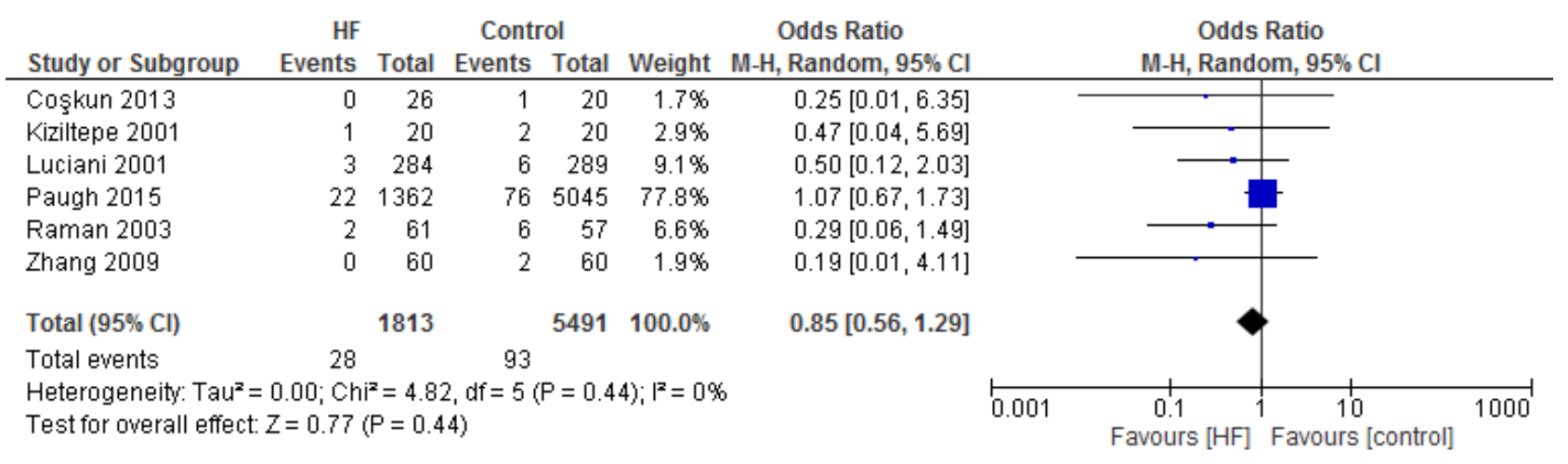

Figure 14. The results of meta-analysis on the association of Ultrafiltration and the stroke/TIA 
Al-Sadawi M (2020) The association of ultrafiltration with the outcomes of cardiopulmonary bypass surgery in adults with cardiovascular disease: The result of a systematic review and meta-analysis

\begin{tabular}{|c|c|c|c|c|c|c|c|c|c|c|}
\hline Study or Subgroup & \multicolumn{2}{|l|}{ HF } & \multicolumn{2}{|c|}{ Control } & Weight & \multicolumn{2}{|l|}{ Odds Ratio } & \multicolumn{2}{|c|}{$\begin{array}{c}\text { Odds Ratio } \\
\text { M-H, Random, } 95 \% \mathrm{Cl}\end{array}$} & \\
\hline El-Tahan 2010 & 0 & 30 & 1 & 30 & $0.9 \%$ & $0.32[0.01,8.24]$ & & & & \\
\hline Luciani 2001 & 5 & 284 & 8 & 289 & $6.6 \%$ & $0.63[0.20,1.95]$ & & & - & \\
\hline Papadopoulos 2013 & 2 & 25 & 2 & 25 & $2.1 \%$ & $1.00[0.13,7.72]$ & & & & \\
\hline Paugh 2015 & 398 & 1362 & 1241 & 5045 & $82.4 \%$ & $1.27[1.11,1.45]$ & & & & \\
\hline Raman 2003 & 6 & 61 & 10 & 57 & $7.2 \%$ & $0.51[0.17,1.52]$ & & & - & \\
\hline Zhang 2009 & 0 & 60 & 1 & 60 & $0.9 \%$ & $0.33[0.01,8.21]$ & & & & \\
\hline Total $(95 \% \mathrm{Cl})$ & & 1822 & & 5506 & $100.0 \%$ & $1.10[0.81,1.49]$ & & & & \\
\hline Total events & 411 & & 1263 & & & & & & & \\
\hline $\begin{array}{l}\text { Heterogeneity: } \mathrm{Tau}^{2}= \\
\text { Test for overall effect: }\end{array}$ & $\begin{array}{l}.02 ; \mathrm{Chi}^{2} \\
=0.63(\mathrm{~F}\end{array}$ & $\begin{array}{l}=5.37, \\
=0.53\end{array}$ & $d f=5(P$ & $=0.37$ & $; 1^{2}=7 \%$ & & 0.002 & $\begin{array}{c}0.1 \\
\text { Favours [HF] }\end{array}$ & Favours [control] & 500 \\
\hline
\end{tabular}

Figure 15. The results of meta-analysis on the association of Ultrafiltration and the acute renal failure

\begin{tabular}{|c|c|c|c|c|c|c|c|c|c|c|}
\hline Study or Subgroup & \multicolumn{2}{|l|}{ HF } & \multicolumn{2}{|c|}{ Control } & Weight & $\begin{array}{c}\text { Odds Ratio } \\
\text { M-H, Random, } 95 \% \mathrm{Cl}\end{array}$ & \multicolumn{4}{|c|}{$\begin{array}{c}\text { Odds Ratio } \\
\text { M-H, Random, } 95 \% \mathrm{Cl}\end{array}$} \\
\hline de Baar 2013 & 1 & 29 & 2 & 31 & $14.9 \%$ & $0.52[0.04,6.04]$ & & & & \\
\hline Paugh 2015 & 35 & 1362 & 86 & 5045 & $44.2 \%$ & $1.52[1.02,2.26]$ & & & - & \\
\hline Soliman 2016 & 17 & 138 & 38 & 145 & $40.9 \%$ & $0.40[0.21,0.74]$ & & & & \\
\hline Total $(95 \% \mathrm{Cl})$ & & 1529 & & 5221 & $100.0 \%$ & $0.75[0.24,2.36]$ & & & & \\
\hline Total events & 53 & & 126 & & & & & & & \\
\hline $\begin{array}{l}\text { Heterogeneity: Tau } \\
\text { Test for overall effec }\end{array}$ & $\begin{array}{l}0.74 ; \mathrm{Ch} \\
\mathrm{Z}=0.50\end{array}$ & $\begin{array}{l}x=12 . \\
P=0.6\end{array}$ & $\begin{array}{l}99, \mathrm{df}=2 \\
2)\end{array}$ & $(\mathrm{P}=0$. & $002) ;\left.\right|^{2}=$ & $85 \%$ & 0.001 & $\begin{array}{c}0.1 \\
\text { Eavours [HF] }\end{array}$ & $\begin{array}{c}10 \\
\text { Favours [control] }\end{array}$ & 1000 \\
\hline
\end{tabular}

Figure 16. The results of meta-analysis on the association of Ultrafiltration and the IABP

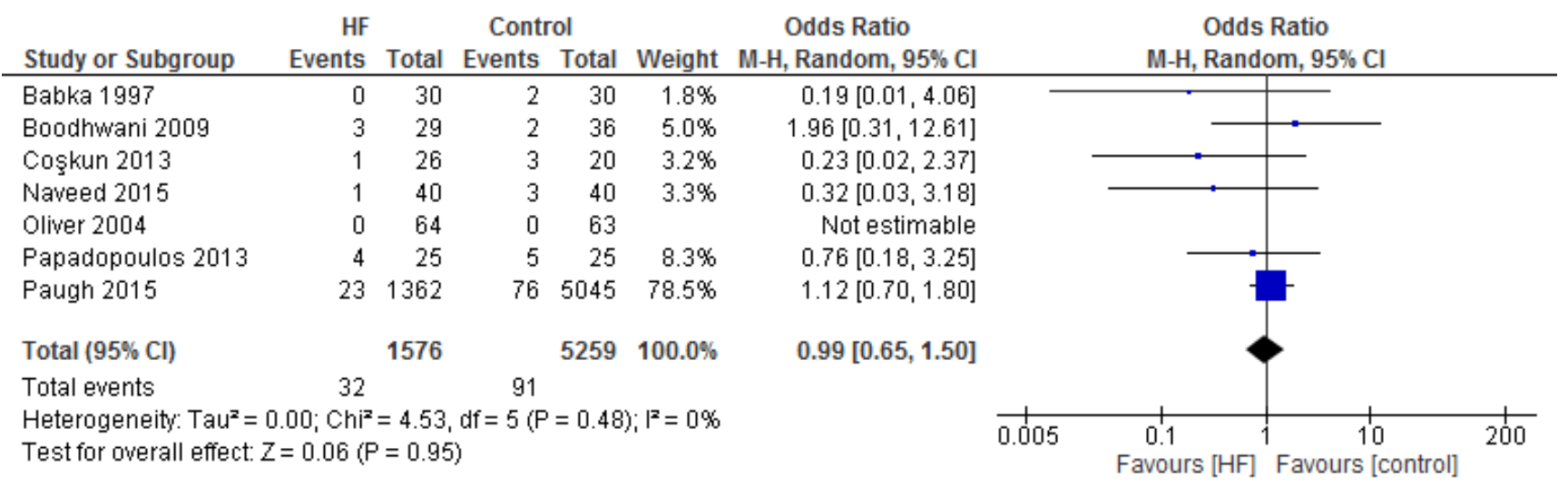

Figure 17. The results of meta-analysis on the association of Ultrafiltration and the reoperation

in patients with chronic kidney disease and cardiovascular disease as demonstrated in a study which examined increased UF rates in patients with ESRD and cardiovascular disease [28].

The length of stay in the ICU was also significantly decreased (mean difference - 0.16 days) in the UF groups compared to the control groups. However, this statistical significance does not pertain a clinical significance as the duration of difference was marginal. Total time on ventilator, hospital length of stay, myocardial infarction, surgical site infections, arrhythmia, stroke, low cardiac output and the need for intra-aortic balloon pump, and reoperation were equivalent between the two groups.

Some limitations have surfaced while doing our review. We employed a broad search strategy but the possibility that important clinical trials were missed remains. Our goal was to report all clinical outcomes reported in different studies, which reflected a heterogeneity in the endpoints of these studies.

\section{Conclusion}

Based on the results from this meta-analysis, the use of UF during or after CBP decreases bleeding and transfusion requirements. No clear impact on mortality was seen and no discernable risk of acute kidney injury. We deduced that UF appears to be useful in adult cardiac surgery given the reductions in bleeding and blood product needs. It should be noted, however, that UF in patients with initially reduced kidney function should be used with caution. There are still gaps in evidence and larger randomized clinical trials should be performed. 
Al-Sadawi M (2020) The association of ultrafiltration with the outcomes of cardiopulmonary bypass surgery in adults with cardiovascular disease: The result of a systematic review and meta-analysis

\section{References}

1. Boodhwani M, Hamilton A, de Varennes B, Mesana T, Williams K, et al. (2010) A multicenter randomized controlled trial to assess the feasibility of testing modified ultrafiltration as a blood conservation technology in cardiac surgery. $J$ Thorac Cardiovasc Surg 139: 701-706. [Crossref]

2. Tassani P, Richter JA, Barankay A, Braun SL, Haehnel C, et al. (1999) Does high-dose methylprednisolone in aprotinin-treated patients attenuate the systemic inflammatory response during coronary artery bypass grafting procedures? J Cardiothorac Vasc Anesth 13: 165-172. [Crossref]

3. Boodhwani M, Williams K, Babaev A, Gill G, Saleem N, et al. (2006) Ultrafiltration reduces blood transfusions following cardiac surgery: A meta-analysis. Eur $J$ Cardiothorac Surg 30: 892-897. [Crossref]

4. Weber CF, Jámbor C, Strasser C, Moritz A, Papadopoulos N, et al. (2011) Normovolemic modified ultrafiltration is associated with better preserved platelet function and less postoperative blood loss in patients undergoing complex cardiac surgery: a randomized and controlled study. J Thorac Cardiovasc Surg 141: 1298-1304. [Crossref]

5. Paugh TA, Dickinson TA, Martin JR, Hanson EC, Fuller J, et al. (2015) Impact of Ultrafiltration on Kidney Injury After Cardiac Surgery: The Michigan Experience. Ann Thorac Surg 100: 1683-1688. [Crossref]

6. Groom RC, Froebe S, Martin J, Manfra MJ, Cormack JE, et al. (2005) Update on pediatric perfusion practice in North America: 2005 survey. $J$ Extra Corpor Technol 37: 343-350. [Crossref]

7. Babka RM, Petress J, Briggs R, Helsal R, Mack J (1997) Conventional haemofiltration during routine coronary bypass surgery. Perfusion 12: 187-192. [Crossref]

8. Blanchard N, Toque Y, Trojette F, Quintard JM, Benammar A, et al. (2000) Hemodynamic and echocardiographic effects of hemofiltration performed during cardiopulmonary bypass. J Cardiothorac Vasc Anesth 14: 393-398.

9. Bogă M, Islamoğlu, Badak I, Cikirikçioğlu M, Bakalim T, et al. (2000) The effects of modified hemofiltration on inflammatory mediators and cardiac performance in coronary artery bypass grafting. Perfusion 15: 143-150. [Crossref]

10. Coskun I.

11. El-Tahan MR, Hamad RA, Ghoneimy YF, El Shehawi MI, Shafi MA (2010) A prospective, randomized study of the effects of continuous ultrafiltration in hepatic patients after cardiac valve surgery. J Cardiothorac Vasc Anesth 24: 63-68. [Crossref]

12. de Baar M, Diephuis JC, Moons KG, Holtkamp J, Hijman R, et al. (2003) The effect of zero-balanced ultrafiltration during cardiopulmonary bypass on $\mathrm{S} 100 \mathrm{~b}$ release and cognitive function. Perfusion 18: 9-14. [Crossref]

13. Kiziltepe U, Uysalel A, Corapcioglu T, Dalva K, Akan H, et al. (2001) Effects of combined conventional and modified ultrafiltration in adult patients. Ann Thorac Surg 71: 684-693. [Crossref]

14. Luciani GB, Menon T, Vecchi B, Auriemma S, Mazzucco A (2001) Modified ultrafiltration reduces morbidity after adult cardiac operations: a prospective, randomized clinical trial. Circulation 104: I253-259. [Crossref]
15. Matata BM, Scawn N, Morgan M, Shirley S, Kemp I, et al. (2015) A SingleCenter Randomized Trial of Intraoperative Zero-Balanced Ultrafiltration During Cardiopulmonary Bypass for Patients With Impaired Kidney Function Undergoing Cardiac Surgery. J Cardiothorac Vasc Anesth 29: 1236-1247. [Crossref]

16. Oliver WC, Nuttall GA, Orszulak TA, Bamlet WR, Abel MD, et al. (2004) Hemofiltration but not steroids results in earlier tracheal extubation following cardiopulmonary bypass: a prospective, randomized double-blind trial. Anesthesiology 101: 327-339. [Crossref]

17. Papadopoulos N, Bakhtiary F, Grün V, Weber CF, Strasser C, et al. (2013) The effect of normovolemic modified ultrafiltration on inflammatory mediators, endotoxins, terminal complement complexes and clinical outcome in high-risk cardiac surgery patients. Perfusion 28: 306-314. [Crossref]

18. Soliman R, Fouad E, Belghith M, Abdelmageed T (2016) Conventional hemofiltration during cardiopulmonary bypass increases the serum lactate level in adult cardiac surgery. Ann Card Anaesth 19: 45-51. [Crossref]

19. Zhang T, Jiang SL, Gao CQ, Luo J, Ma L, et al. (2011) Effect of subzero-balanced ultrafiltration on lung gas exchange capacity after cardiopulmonary bypass in adult patients with heart valve disease. Heart Surg Forum 14: E22-27. [Crossref]

20. Naveed D, Khan RA, Malik A, Shah SZ, Ullah I, et al. (2016) Role of modified ultrfiltration in adult cardiac surgery: a prospective randomized control trial. $J$ Ayub Med Coll Abbottabad 28: 22-25. [Crossref]

21. Torina AG, Silveira-Filho LM, Vilarinho KA, Eghtesady P, Oliveira PP, et al. (2012) Use of modified ultrafiltration in adults undergoing coronary artery bypass grafting is associated with inflammatory modulation and less postoperative blood loss: a randomized and controlled study. J Thorac Cardiovasc Surg 144: 663-670. [Crossref]

22. Grünenfelder J, Zünd G, Schoeberlein A, Maly FE, Schurr U, et al. (2000) Modified ultrafiltration lowers adhesion molecule and cytokine levels after cardiopulmonary bypass without clinical relevance in adults. Eur J Cardiothorac Surg 17: 77-83. [Crossref]

23. Tallman RD, Dumond M, Brown D (2002) Inflammatory mediator removal by zero-balance ultrafiltration during cardiopulmonary bypass. Perfusion 17: 111-115. [Crossref]

24. Raman JS, Hata M, Bellomo R, Kohchi K, Cheung HL, et al. (2003) Hemofiltration during cardiopulmonary bypass for high risk adult cardiac surgery. Int $J$ Artif Organs 26: 753-757. [Crossref]

25. Steffens TG, Kohmoto T, Edwards N, Wolman RL, Holt DW (2008) Effects of modified ultrafiltration on coagulation as measured by the thromboelastograph. J Extra Corpor Technol 40: 229-233. [Crossref]

26. Kosour C, Dragosavac D, Antunes N, Almeida de Oliveira RA, Martins Oliveira PP, et al. (2016) Effect of Ultrafiltration on Pulmonary Function and Interleukins in Patients Undergoing Cardiopulmonary Bypass. J Cardiothorac Vasc Anesth 30: 884-890. [Crossref]

27. Berdat PA, Eichenberger E, Ebell J, Pfammatter JP, Pavlovic M, et al. (2004) Elimination of proinflammatory cytokines in pediatric cardiac surgery: analysis of ultrafiltration method and filter type. J Thorac Cardiovasc Surg 127: 1688-1696. [Crossref]

28. Flythe JE, Brunelli SM (2011) The risks of high ultrafiltration rate in chronic hemodialysis: implications for patient care. Semin Dial 24: 259-265. [Crossref]

Copyright: (C2020 Al-Sadawi M. This is an open-access article distributed under the terms of the Creative Commons Attribution License, which permits unrestricted use, distribution, and reproduction in any medium, provided the original author and source are credited. 